$\mathrm{Cd}, \mathrm{Fe}$ and $\mathrm{Zn}$ Content of the Epiphytic Lichen Hypogymnia Physodes in a Finnish Suburb

\title{
Lodenius, M.
}

Elsevier Science Publishers B. V.

1983

Lodenius, M. and Kumpulainen, J. 1983. Cd, Fe and Zn Content of the Epiphytic Lichen Hypogymnia Physodes in a Finnish Suburb. The Science of the Total Environment 32: 81-95.

http://hdl.handle.net/1975/199

Downloaded from Helda, University of Helsinki institutional repository.

This is an electronic reprint of the original article.

This reprint may differ from the original in pagination and typographic detail.

Please cite the original version. 


\title{
Cd, Fe AND Zn CONTENT OF THE EPIPHYTIC LICHEN HYPOGYMNIA PHYSODES IN A FINNISH SUBURB
}

\author{
MARTIN LODENIUS
}

Department of Environmental Science, University of Helsinki, SF-00710 Helsinki 71 (Finland)

JORMA KUMPULAINEN

Department of Food Chemistry and Technology, University of Helsinki, SF-00710 Helsinki 71 (Finland)

(Receiveà October 30th, 1982; accepted May 2nd, 1983)

\begin{abstract}
The epiphytic lichen Hypogymnia physodes was analysed for its content of cadmium, iron and zinc in a suburb of Helsinki. The metal contents were slightly higher than those from unpolluted areas in central Finland. Elevated concentrations were found in the vicinity of a big shipyard.
\end{abstract}

\section{INTRODUCTION}

Mosses and lichens have often been successfully used as monitors of airborne pollutants. The epiphytic lichen Hypogymnia physodes (L.) Nyl. has proved to be suitable for investigation of both long-range transport of heavy metals (Solberg and Selmer-Olsen, 1978; Lodenius, 1981) and local pollution (Steinnes and Krog, 1976; Laaksovirta and Olkkonen, 1977; Lodenius and Laaksovirta, 1979; Pilegaard, 1979; Pilegaard et al., 1979).

The aim of this study was to investigate the distribution of cadmium, iron and zinc in a surburb of Helsinki with only a few metal emitting sources.

\section{STUDY AREA, MATERIAL AND METHODS}

The suburb Vuosaari is situated $15 \mathrm{~km}$ east of the centre of Helsinki on the Gulf of Finland. There are approximately 15,000 inhabitants and the oniy industrial plant of importance is a big shipyard. Almost all of the flats 
are oil-heated and two lichen deserts (areas with none or only severely stunted Hypogymnia) can be found (Fig. 1). However, the contribution of metals from oil combustion in domestic homes is quite small. If the metal contents of heavy fuel oil reported by Andersson and Grennfelt (1973) are used, the annual $\mathrm{Cd}$ emission from heating in Vuosaari may be estimated as some hundred grams, that of $\mathrm{Fe}$ as about $50 \mathrm{~kg}$ and that of $\mathrm{Zn}$ as about $10 \mathrm{~kg}$. In a survey of the heavy metal contents of fungi (Lodenius et al., 1981), very high $\mathrm{Cd}$ content was found in some mushroom species in this suburb, but no reason for this could be detected.

40 Samples of Hypogymnia physodes were collected in the winter of 1980. Six control samples were obtained from unpolluted, rural localities in central Finland (Juva, Kontiolahti, Nurmes, Polvijärvi, Pyhäntä and Siilinjärvi). Each sample was collected from the bark of 3-4 pines (Pinus sylvestris L.) at a heigh of $1-1.5 \mathrm{~m}$ above ground. The samples were ovendried at $+50^{\circ} \mathrm{C}$, homogenized and dissolved in concentrated $\mathrm{HNO}_{3}$.

The $\mathrm{Cd}$ content was measured using AAS (Perkin-Elmer 5000 equipped with a HGA 500 graphite furnace, an As 40 autosampler, a PRS 10 printer and a model 56 chart recorder). $\mathrm{D}_{2}$ background correction was used. The $\mathrm{Fe}$ and $\mathrm{Zn}$ contents were measured with flame AAS (Perkin-Elmer $290 \mathrm{~B}$ ). All the measurements were made according to the Perkin-Elmer instruction manuals.

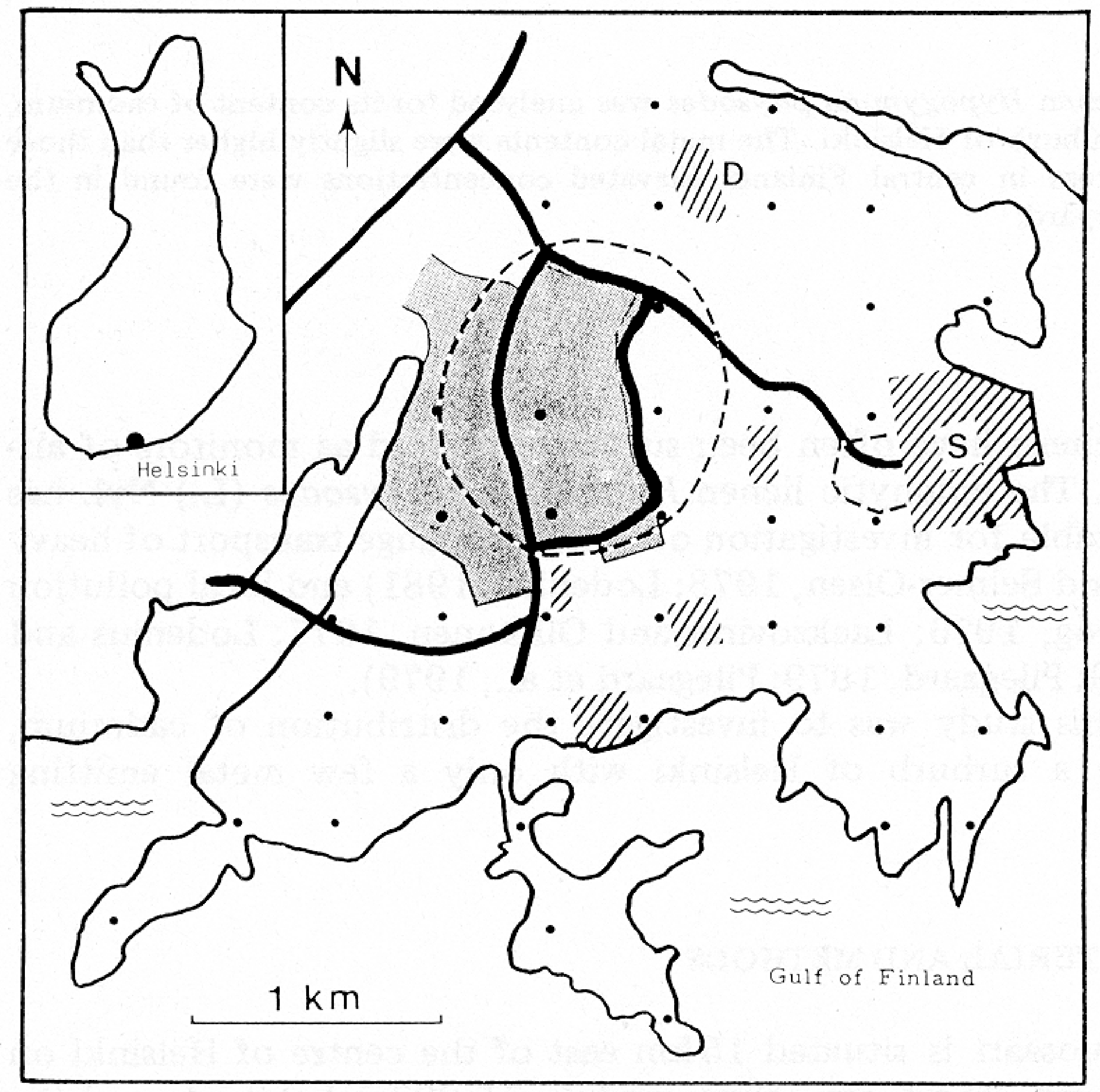

Fig. 1. The study area. Main roads (solid lines), residential area (dotted), lichen deserts (broken lines), sampling points (dots) and industrial areas (diagonal stripes) are marked. $\mathrm{S}=$ shipyard, $\mathrm{D}=$ dumping ground. 


\section{RESULTS AND DISCUSSION}

The mean $\mathrm{Cd}$ and $\mathrm{Zn}$ contents of the lichens in Vuosaari were significantly higher $(p<0.05)$ than those of the control samples, while the mean Fe content was only slightly higher. The background $\mathrm{Cd}$ content in Vuosaari (Table 1) was very similar to that reported by Pilegaard et al. (1979) from rural sites in Denmark $(0.35 \mathrm{mg} / \mathrm{kg})$. The maximum Cd content in Vuosaari $(1.6 \mathrm{mg} / \mathrm{kg})$ was surprisingly high, considering it was found in the forest area in northern Vuosaari (Fig. 2). This value approximates that found near a Swedish brass foundry (max. $1.7 \mathrm{mg} / \mathrm{kg}$; Folkeson, 1979) but is significantly lower than the maximum concentrations in Hypogymnia transplants near a Danish steelworks $(21.7 \mathrm{mg} / \mathrm{kg}$; Pilegaard, 1979). Slightly elevated Cd concentrations were also found in the vicinity of the shipyard, but there seem to be no large $\mathrm{Cd}$ emissions in this area. The high Cd content in mushrooms is obviously not caused by air-borne pollution.

The mean $\mathrm{Fe}$ content of the lichens was at the same level as reported by Seaward (1974) and Pilegaard et al. (1979). Slightly elevated concentrations were found near the shipyard, but all the values were significantly lower than the maximum values reported from the vicinity of a Finnish metal and chemical industrial complex $(21,000 \mathrm{mg} / \mathrm{kg}$; Laaksovirta and Olkkonen, 1977) and the Danish steelworks (Pilegaard, 1979).

The $\mathrm{Zn}$ content of Hypogymnia physodes in Vuosaari was also at the level reported for unpolluted areas (Mäkinen and Pakarinen, 1977; Schönbeck, 1974; Seaward, 1974; Pilegaard et al., 1979) and thus considerably lower than the maximum values from the Finnish industrial complex $(5,600 \mathrm{mg} / \mathrm{kg}$; Laaksovirta and Olkkonen, 1977), the Danish steelworks $(22,000 \mathrm{mg} / \mathrm{kg}$; Pilegaard, 1979) and the Swedish brass foundry $(450 \mathrm{mg} / \mathrm{kg}$; Folkeson, 1979). The $\mathrm{Zn}$ concentrations were quite evenly distributed in Vuosaari with slightly elevated values both in the residential area and near the shipyard.

The distribution of the metals shows higher values in the central and eastern parts of Vuosaari, with a maximum near the shipyard. The low

TABLE 1

$\mathrm{Cd}$, Fe AND $\mathrm{Zn}$ CONTENTS (mg/kg dry weight) OF HYPOGYMNIA PHYSODES IN VUOSAARI $(n=40)$ COMPARED WITH THE CONTROL AREAS $(n=6)$

\begin{tabular}{llll}
\hline & & Vuosaari & Control areas \\
\hline Cd & Mean \pm S.D. & $0.50 \pm 0.27$ & $0.29 \pm 0.12$ \\
& Range & $0.15-1.6$ & $0.13-0.48$ \\
$\mathrm{Fe}$ & Mean \pm S.D. & $1800 \pm 1500$ & $1500 \pm 830$ \\
& Range & $770-4300$ & $660-3000$ \\
$\mathrm{Zn}$ & Mean \pm S.D. & $140 \pm 34$ & $98 \pm 17$ \\
& Range & $65-210$ & $77-120$ \\
\hline
\end{tabular}



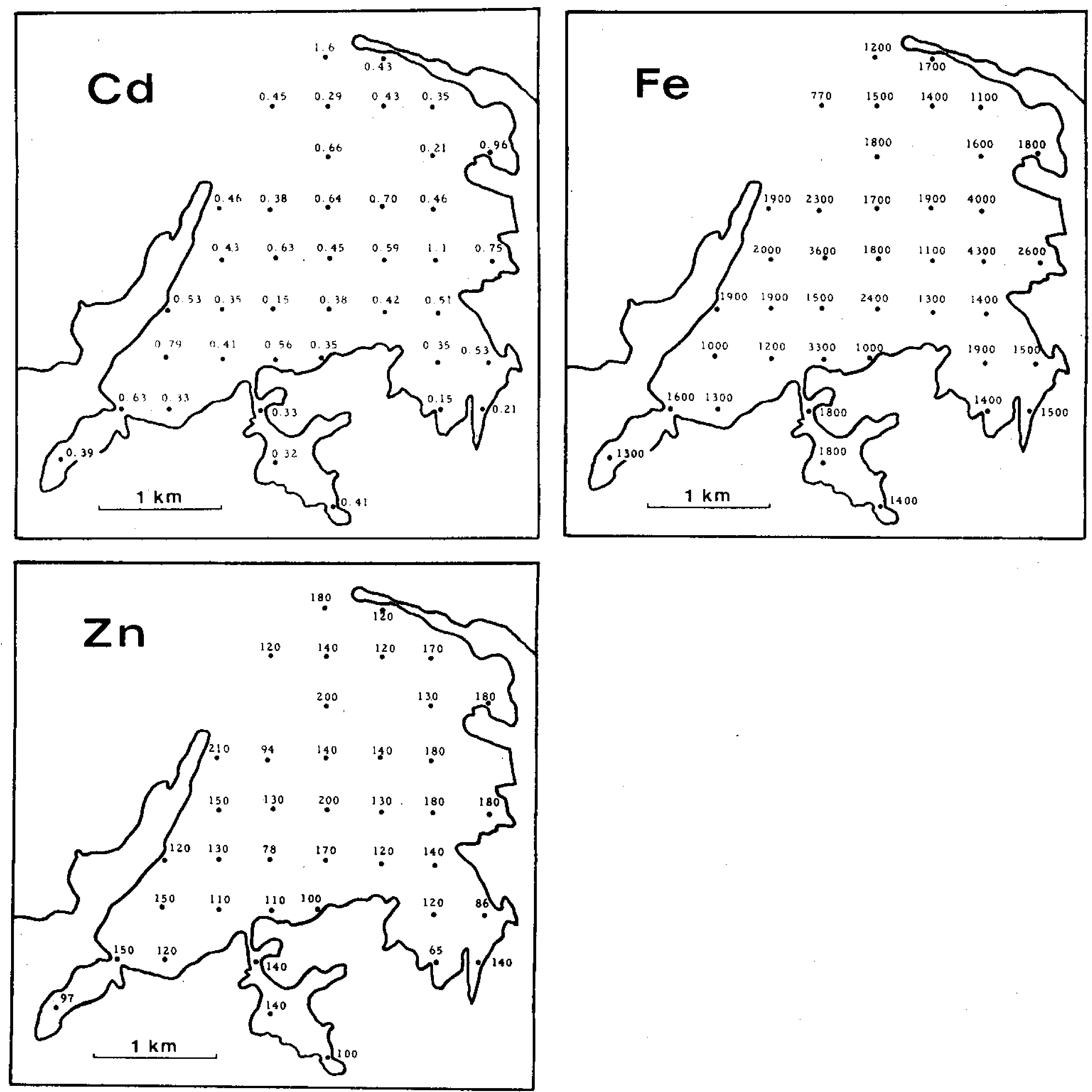

Fig. 2. Cd, Fe and $\mathrm{Zn}$ content (mg/kg dry weight) of Hypogymnia physodes in Vuosaari.

values in the northern part of the residential area may be due to the fact that the lichens were severely stunted (cf. Steinnes and Krog, 1976; Lodenius, 1981). The occurrence of $\mathrm{Cd}$ in the environment is often associated with $\mathrm{Zn}$ and a significant $(r=0.484, p<0.01)$ correlation between these two elements was found. No correlation was observed between $\mathrm{Fe}$ and the other metals.

\section{ACKNOWLEDGEMENTS}

We are indebted to Jari Lehto and Esa Tulisalo for technical assistance. 


\section{REFERENCES}

Andersson, G. and P. Grennfelt, 1973. Determination of heavy metals in fuel oils and an estimation of the emissions of heavy metals from oil combustion. Rep. Swedish Water Air Pollut. Res. Lab. B 138.

Folkeson, L., 1979. Interspecies calibration of heavy-metal concentrations in nine mosses and lichens: applicability to deposition measurements. Water Air Soil Pollut., 11: 253-260.

Laaksovirta, K. and H. Olkkonen, 1977. Effect of air pollution on epiphytic lichen vegetation and element contents of a lichen and pine needles at Valkeakoski, S. Finland. Ann. Bot. Fennici, 16: 285-296.

Lodenius, M., 1981. Regional distribution of mercury in Hypogymnia physodes. Ambio, $10: 183-184$.

Lodenius, M., T. Kuusi, K. Laaksovirta, H. Liukkonen-Lilja and S. Piepponen, 1981. Sienten kadmium-, elohopea- ja lyijypitoisuuksista Suomessa. Ympäristö ja Terveys, 12: 399-408.

Lodenius, M. and K. Laaksovirta, 1979. Mercury content of Hypogymnia physodes and pine needles affected by a chlor-alkali works at Kuusankoski, SE Finland. Ann. Bot. Fennici, 16: 7-10.

Mäkinen, A. and P. Pakarinen, 1977. Raskasmetalli-laskeumien seuranta sammalten ja jäkälien avulla. (Summary: Comparison of some forest and bog plants in heavy metal surveys). Ympäristö ja Terveys, $8: 170-180$.

Pilegaard, K., 1979. Heavy metals in bulk precipitation and transplanted Hypogymnia physodes and Dicranowoisia cirrata in the vicinity of a Danish steelworks. Water Air Soil Pollut., 11: 77-91.

Pilegaard, K., L. Rasmussen and H. Gydesen, 1979. Atmospheric background deposition of heavy metals in Denmark monitored by epiphytic cryptogams. J. Appl. Ecol., 16: $843-853$.

Schönbeck, H., 1974. Nachweiss schwermetallhaltiger Immissionen durch ausgewählte pflanzliche Indikatoren. Staub Reinhalt. Luft, 34: 214-224.

Seaward, M., 1974. Some observations on heavy metal toxicity and tolerance in lichens. Lichenologist, 6: 158-164.

Solberg, Y. and A.R. Selmer-Olsen, 1978. Studies on the chemistry of lichens and mosses. XVII. Mercury content of several lichen and moss species collected in Norway. Bryologist, 81 : 144-149.

Steinnes, E. and H. Krog, 1976. Mercury, arsenic and selenium fall-out from an industrial complex studied by means of lichen transplants. Oikos, 28: 160-164. 